\title{
Methodological considerations in cost of illness studies on Alzheimer disease
}

\author{
Nagede Costa ${ }^{1,2^{*}}$, Helene Derumeaux ${ }^{1}$, Thomas Rapp ${ }^{4}$, Valérie Garnault ${ }^{1}$, Laura Ferlicoq ${ }^{1}$, Sophie Gillette ${ }^{2,3,4}$, \\ Sandrine Andrieu ${ }^{2,3,6}$, Bruno Vellas ${ }^{2,3,5}$, Michel Lamure ${ }^{7}$, Alain Grand ${ }^{2,3,6}$ and Laurent Molinier ${ }^{1,2,3}$
}

\begin{abstract}
Cost-of-illness studies (COI) can identify and measure all the costs of a particular disease, including the direct, indirect and intangible dimensions. They are intended to provide estimates about the economic impact of costly disease. Alzheimer disease (AD) is a relevant example to review cost of illness studies because of its costliness. The aim of this study was to review relevant published cost studies of AD to analyze the method used and to identify which dimension had to be improved from a methodological perspective. First, we described the key points of cost study methodology. Secondly, cost studies relating to AD were systematically reviewed, focussing on an analysis of the different methods used. The methodological choices of the studies were analysed using an analytical grid which contains the main methodological items of $\mathrm{COI}$ studies. Seventeen articles were retained. Depending on the studies, annual total costs per patient vary from $\$ 2,935$ to $\$ 52,954$. The methods, data sources, and estimated cost categories in each study varied widely. The review showed that cost studies adopted different approaches to estimate costs of $A D$, reflecting a lack of consensus on the methodology of cost studies. To increase its credibility, closer agreement among researchers on the methodological principles of cost studies would be desirable.
\end{abstract}

Keywords: Alzheimer disease, Cost study, Dementia, Economic, Evaluation, Review

\section{Review}

\section{Introduction}

Cost-of-Illness (COI) studies aim to identify and measure all the costs of a disease [1]. They describe and estimate the economic burden of a specific disease to a society, and therefore the savings that could be done if the disease were to be eradicated [2]. COI studies as decision making tool has been debated, but they may be useful by educating, informing and enlightening policy makers in planning and financing [3]. COI studies are particularly relevant in chronic diseases that weigh heavily on health expenditures. Dementia is characterized by a gradual and irreversible impairment of the intellect, memory, and personality. Alzheimer disease (AD) accounts for $60 \%$ to $80 \%$ of all dementia cases and its prevalence will increase with the life expectancy growth [4]. There are 35, 6 million demented people in 2011, increasing to 115,4 million by

\footnotetext{
* Correspondence: costa.n@chu-toulouse.fr

'Department of Medical Information, University Hospital of Toulouse,

Toulouse F-31059, France

${ }^{2}$ UMR 1027, INSERM, Toulouse F-31059, France

Full list of author information is available at the end of the article
}

2050 [5]. Disease worldwide costs were US\$ 604 billion in 2011, which $84 \%$ were attributable to informal and formal costs. COI studies are the initial step in an economic evaluation. Few cost-effectiveness analyses in AD drug treatment show divergent results in costs saving [6,7], probably because of different methodologies. So, it is necessary to accurately assess AD costs to show the potential economic impact of new therapeutic or preventive strategies. Three articles were previously published on the methodology of AD costs [8-10], but they were either focus on European studies including other dementia (not on $\mathrm{AD}$ specifically), or focus on informal costs and not focus on COI studies. This study aims to review relevant published AD COI studies, to analyze the methods used and to identify the points that should be improved in order to obtain convincing results from a methodological perspective. First, we provided a general description of the $\mathrm{COI}$ method. And then, we systematically reviewed $\mathrm{AD}$ costs studies, analyzing the different methods used.

\section{Springer}

(c) 2012 Costa et al.; licensee Springer. This is an Open Access article distributed under the terms of the Creative Commons Attribution License (http://creativecommons.org/licenses/by/2.0), which permits unrestricted use, distribution, and reproduction in any medium, provided the original work is properly cited. 


\section{Methods}

Cost study

To conduct a COI study, it is necessary to define disease, epidemiological approach, type of costs, and study perspective. Subsequently, resource consumption data and unit costs can be gathered, and the results presented and methodically discussed, in conjunction with sensitivity analysis to test their robustness. A checklist (Table 1), containing its items, was developped on the model described by Drummond et al. [11] and adapted to COI by Molinier et al. [12]. An equal weight was given to each item. The final score was the sum of the eleven individual items.

\section{Defining the disease and population}

Illness costs widely depend on how the disease is defined. AD diagnosis is based on Alzheimer's Association criteria (NINCDS-ADRDA) [30] and Diagnostic and Statistical Manual of Mental Disorders criteria (DSM IV) [31]. As costs increase with disease severity [32-35], disease stage must be specified and measured using validated tools, as Clinical Dementia Rate [36] (CDR) or Mini Mental State Examination (MMSE) [37]. Cost components may vary depending on the living conditions (e.g. home, institution), and therefore must be specified $[33,38]$.

\section{Epidemiological approach}

Prevalence-based COI studies estimate the economic burden to society during a period of time as a result of the prevalence of the disease (e.g. in a given year). Incidence-based studies estimate lifetime costs, and measure the costs of an illness from diagnosis until recovery or another endpoint (e.g. death).

\section{Perspective of the analysis and costs assessed}

A COI study may be conducted from several perspectives that must be specified to check that relevant costs are included. From the healthcare payer perspective, only direct costs incurred by a payer (e.g. national health insurance) are considered. Indirect costs and the patient "out-of-pocket" must also be included in a study which uses societal perspective.

\section{Estimating resource consumption}

Resource consumption estimates vary depending on the data available, but validated tools exist to collect them [39]. In prospective COI studies, events have not occurred yet, so data collection is done by the patients' follow-up, medical records, data from clinical trials and patients or caregiver questionnaires. Conversely, in retrospective COI study, events have already occurred, so data collection must refer to recorded data, either using "Top-down" method (aggregate figures from hospital admissions, mortality, etc.) or "bottom-up" method (by referring to the patients sample record).

\section{Valuation of unit costs}

The COI is estimated by identifying the cost-generating components and by attributing them a monetary value. This is the opportunity cost, the value of the forgone opportunity to use in a different way those resources that are lost due to illness [11]. Direct and indirect costs should be valued to assess the total economic COI. Direct costs measure the resources used to treat an illness and can be estimated by per capita expenditures, national tariffs, market prices, and published studies. Patient charges and tariffs do not give an accurate estimate of the underlying costs. Market prices can be used to value some cost categories like drugs, rehabilitation items (e.g. eyeglasses, etc.). Direct costs can also be valued with care facilities estimates, through the analytical account system which specified distribution properties. Indirect costs measure the loss of productivity, the effect of the illness on the patient or caregiver abilities to work. Three methods are used to value indirect costs: the Human Capital Approach (HCA) [40], the Friction Cost Method [41] and the Willingness to pay approach [42]. Informal care is an unpaid care often provided by relatives and plays a substantial role in the AD patient's total care. Two methods are mainly used to value the shadow price of informal care time. The opportunity cost approach values the opportunity forgone as a result of caregiving and the replacement cost approach values the caregiving time spent at a price of a close substitute $[9,43,44]$.

\section{Discounting costs}

Discounting captures individual preferences for income today rather than income in the future and is frequently applied when COI studies are considered over several years. In the USA, they estimate the discount rate at $3 \%$ [45]. The following equation is applied to estimate costs:

$$
C_{a}=C_{t} \sum_{n=1}^{t}(1+r)^{-n}
$$

Where: $C_{a}=$ present value of cost strategy, $C_{t}=$ value of cost strategy in year $\mathrm{t}, \mathrm{r}=$ discount rate, $\mathrm{t}=$ time period.

\section{Sensitivity analysis}

Sensitivity analysis is recommended because COI studies contain uncertainties. It allows testing the robustness of the results by varying in range key variables (e.g., prevalence, unit costs, etc.) [46]. It seems more credible to present a range of possible illness costs. 
Table 1 Answers to the methodological questions by study

\begin{tabular}{|c|c|c|c|c|c|c|c|c|c|c|c|c|c|c|c|c|c|c|c|c|c|c|c|c|c|c|c|}
\hline & \multicolumn{3}{|c|}{ All studies } & \multicolumn{3}{|c|}{$\begin{array}{l}\text { Lopez Bastida } \\
\text { et al. [13] }\end{array}$} & \multicolumn{3}{|c|}{$\begin{array}{c}\text { Coduras et al. } \\
{[14]}\end{array}$} & \multicolumn{3}{|c|}{$\begin{array}{c}\text { Rigaud et al. } \\
{[15]}\end{array}$} & \multicolumn{3}{|c|}{$\begin{array}{c}\text { Kronborg } \\
\text { Andersen et al. [16] }\end{array}$} & \multicolumn{3}{|c|}{$\begin{array}{c}\text { Cavallo et al. } \\
{[17]}\end{array}$} & \multicolumn{3}{|c|}{$\begin{array}{l}\text { Mesterton et al. } \\
{[18]}\end{array}$} & \multicolumn{3}{|c|}{$\begin{array}{c}\text { Kiencke et al. } \\
\text { [19] }\end{array}$} & \multicolumn{3}{|c|}{$\begin{array}{c}\text { Leon et al. } \\
{[20]}\end{array}$} \\
\hline & Yes & $\mathbf{P}$ & No & Yes & $P$ & No & Yes & $P$ & No & Yes & $P$ & No & Yes & $P$ & No & Yes & $P$ & No & Yes & $P$ & No & Yes & $P$ & No & Yes & $P$ & No \\
\hline $\begin{array}{l}1 \text { Was a clear definition of the } \\
\text { illness given? }\end{array}$ & 10 & 5 & 2 & & $P$ & & Yes & & & Yes & & & Yes & & & & & No & & $P$ & & & $P$ & & Yes & & \\
\hline $\begin{array}{l}2 \text { Were epidemiological sources } \\
\text { carefully described? }\end{array}$ & 13 & 3 & 1 & Yes & & & Yes & & & Yes & & & Yes & & & Yes & & & & P & & Yes & & & Yes & & \\
\hline $\begin{array}{l}3 \text { Were costs sufficiently } \\
\text { disaggregated? }\end{array}$ & 12 & 0 & 5 & Yes & & & Yes & & & & & No & Yes & & & Yes & & & Yes & & & Yes & & & & & No \\
\hline $\begin{array}{l}4 \text { Were activity data sources } \\
\text { carefully described? }\end{array}$ & 15 & 1 & 1 & Yes & & & Yes & & & Yes & & & Yes & & & Yes & & & Yes & & & & $P$ & & Yes & & \\
\hline $\begin{array}{l}5 \text { Were activity data appropriately } \\
\text { assessed? }\end{array}$ & 6 & 9 & 2 & Yes & & & & P & & & P & & & $P$ & & & $P$ & & Yes & & & & & No & Yes & & \\
\hline $\begin{array}{l}6 \text { Were the sources of all cost } \\
\text { values analytically described? }\end{array}$ & 10 & 4 & 3 & Yes & & & Yes & & & Yes & & & Yes & & & & $P$ & & Yes & & & & & No & Yes & & \\
\hline $\begin{array}{l}7 \text { Were unit costs appropriately } \\
\text { valued? }\end{array}$ & 7 & 5 & 5 & Yes & & & Yes & & & & P & & & $P$ & & & $P$ & & Yes & & & & & No & Yes & & \\
\hline $\begin{array}{l}8 \text { Were the methods adopted } \\
\text { carefully explained? }\end{array}$ & 11 & 6 & 0 & Yes & & & Yes & & & Yes & & & Yes & & & & $P$ & & Yes & & & & $P$ & & Yes & & \\
\hline 9 Were costs discounted? & 0 & 2 & 15 & & & No & & & No & & & No & & & No & & & No & & & No & & $P$ & & & & No \\
\hline $\begin{array}{l}10 \text { Were the major assumptions } \\
\text { tested in a sensitivity analysis? }\end{array}$ & 3 & 0 & 14 & & & No & Yes & & & & & No & & & No & & & No & & & No & Yes & & & & & No \\
\hline $\begin{array}{l}11 \text { Was the presentation of } \\
\text { study results consistent with } \\
\text { the methodology of study? }\end{array}$ & 13 & 4 & 0 & Yes & & & Yes & & & Yes & & & Yes & & & Yes & & & Yes & & & Yes & & & & $P$ & \\
\hline 12 Total score by study & 100 & 39 & 48 & 8 & 1 & 2 & 9 & 1 & 1 & 6 & 2 & 3 & 7 & 2 & 2 & 4 & 4 & 3 & 7 & 2 & 2 & 4 & 4 & 3 & 7 & 1 & 3 \\
\hline
\end{tabular}

Total score by study was the sum of answers; P, Partially. 
Table 1 Answers to the methodological questions by study (Continued)

\begin{tabular}{|c|c|c|c|c|c|c|c|c|c|c|c|c|c|c|c|c|c|c|c|c|c|c|c|c|c|c|c|}
\hline & \multicolumn{3}{|c|}{$\begin{array}{l}\text { Hay et al. } \\
\text { [21] }\end{array}$} & \multicolumn{3}{|c|}{$\begin{array}{l}\text { Rice et al. } \\
\text { [22] }\end{array}$} & \multicolumn{3}{|c|}{$\begin{array}{l}\text { Leon et al. } \\
\text { [23] }\end{array}$} & \multicolumn{3}{|c|}{$\begin{array}{l}\text { Ostbye et al. } \\
\text { [24] }\end{array}$} & \multicolumn{3}{|c|}{$\begin{array}{l}\text { Zencir et al. } \\
\text { [25] }\end{array}$} & \multicolumn{3}{|c|}{$\begin{array}{l}\text { Wang et al. } \\
\text { [26] }\end{array}$} & \multicolumn{3}{|c|}{$\begin{array}{l}\text { Suh et al. } \\
\text { [27] }\end{array}$} & \multicolumn{3}{|c|}{$\begin{array}{l}\text { Beeri et al. } \\
\text { [28] }\end{array}$} & \multicolumn{3}{|c|}{$\begin{array}{l}\text { Allegri et al. } \\
\text { [29] }\end{array}$} \\
\hline & Yes & $\mathbf{P}$ & No & Yes & $P$ & No & Yes & $P$ & No & Yes & $P$ & No & Yes & $P$ & No & Yes & $P$ & No & Yes & $\mathbf{P}$ & No & Yes & $P$ & No & Yes & $P$ & No \\
\hline $\begin{array}{l}1 \text { Was a clear definition of the } \\
\text { illness given? }\end{array}$ & & & No & & $P$ & & Yes & & & Yes & & & Yes & & & Yes & & & & $P$ & & Yes & & & Yes & & \\
\hline $\begin{array}{l}2 \text { Were epidemiological sources } \\
\text { carefully described? }\end{array}$ & Yes & & & Yes & & & & $P$ & & Yes & & & & $P$ & & Yes & & & Yes & & & & & No & Yes & & \\
\hline $\begin{array}{l}3 \text { Were costs sufficiently } \\
\text { disaggregated? }\end{array}$ & Yes & & & Yes & & & & & No & & & No & Yes & & & Yes & & & & & No & Yes & & & Yes & & \\
\hline $\begin{array}{l}4 \text { Were activity data sources } \\
\text { carefully described? }\end{array}$ & Yes & & & Yes & & & Yes & & & & & No & Yes & & & Yes & & & Yes & & & Yes & & & Yes & & \\
\hline $\begin{array}{l}5 \text { Were activity data appropriately } \\
\text { assessed? }\end{array}$ & Yes & & & Yes & & & & $P$ & & & & No & & $P$ & & & P & & Yes & & & & P & & & $P$ & \\
\hline $\begin{array}{l}6 \text { Were the sources of all cost } \\
\text { values analytically described? }\end{array}$ & Yes & & & & $P$ & & & $P$ & & & & No & & P & & Yes & & & Yes & & & & & No & Yes & & \\
\hline $\begin{array}{l}7 \text { Were unit costs appropriately } \\
\text { valued? }\end{array}$ & Yes & & & & $P$ & & & & No & & & No & & & No & Yes & & & Yes & & & & & No & & $P$ & \\
\hline $\begin{array}{l}8 \text { Were the methods adopted } \\
\text { carefully explained? }\end{array}$ & Yes & & & & $P$ & & & $P$ & & & $P$ & & Yes & & & Yes & & & Yes & & & & P & & Yes & & \\
\hline 9 Were costs discounted? & & $P$ & & & & No & & & No & & & No & & & No & & & No & & & No & & & No & & & No \\
\hline $\begin{array}{l}10 \text { Were the major assumptions } \\
\text { tested in a sensitivity analysis? }\end{array}$ & & & No & & & No & & & No & & & No & & & No & & & No & Yes & & & & & No & & & No \\
\hline $\begin{array}{l}11 \text { Was the presentation of } \\
\text { study results consistent with } \\
\text { the methodology of study? }\end{array}$ & & $P$ & & Yes & & & Yes & & & & $P$ & & Yes & & & Yes & & & Yes & & & & $P$ & & Yes & & \\
\hline 12 Total score by study & 7 & 2 & 2 & 5 & 4 & 2 & 3 & 4 & 4 & 2 & 2 & 7 & 5 & 3 & 3 & 8 & 1 & 2 & 8 & 1 & 2 & 3 & 3 & 5 & 7 & 2 & 2 \\
\hline
\end{tabular}

Total score by study was the sum of answers; P, Partially. 


\section{Presentation of results}

The presentation of COI results should be consistent with collected data and should disaggregate results into as many components as possible with full explanations given for clarity (Table 1 ).

\section{Literature review}

Study selection A bibliographic search was performed on an international medical literature database (Medline). All studies which assessed the economic burden of AD were selected. To be exhaustive, eight keywords combinations were employed: "Alzheimer disease" AND "Cost of illness"; "Alzheimer disease" AND "Economic evaluation"; "Alzheimer disease" AND "Cost study"; "Alzheimer disease" AND "Cost analysis"; "Dementia" AND "Cost of illness"; "Dementia" AND "Economic evaluation"; "Dementia" AND "Cost study"; "Dementia" AND "Cost analysis". This search provided us 2271 papers. We kept the 2033 papers written in English. Among them, we selected articles whose title contained "Dementia" or "Alzheimer disease" (801 papers were removed) AND "Costs" or "Expenses" or "Economic" or "Burden" (another 941 papers were removed). This study focused on the methodology used to estimate AD costs, 137 papers were removed because they were identified as global economic analyses. A hundred and fifty four abstracts were first selected and 46 of them underwent a subsequent full paper reading, thus providing 17 articles. Figure 1 illustrates the literature search, selection process, and presents reasons for excluded studies.

Study review A systematic review was performed. One author (N. Costa) selected abstracts. Six methodologists read the 46 papers retrieved by the search strategy and reviewed the 17 selected papers. With the key methodological points identified in the first part of the paper, they asked questions based on existing checklists for full economic evaluations [47]. The objective was not to establish a criteria hierarchy by using different weights, but to use these criteria to analyze the methods used. Each study was assessed separately by the reviewers. Finally, a consensus was reached by discussion. Then, all authors, both clinicians and methodologists, discussed the results.

\section{Results}

Seventeen studies met our criteria (Tables 2, 3). Seven studies were conducted in Europe [13-19], 5 in North America [20-24], 4 in Asia [25-28] and 1 in South America [29]. Fifteen studies selected a sample ranging in size from 42 to 21512 patients [13-20,22-29].

\section{Defining the disease and population}

AD was defined with NINCDS-ADRDA criteria for 4 studies [20,23,28,29], with DSM criteria for 2 studies $[25,26]$, with both criteria for 4 studies [14-16,24] and with ICD-10 for another study [19]. Six studies did not specify the criteria used $[13,17,18,21,22,27]$. Disease severity was measured with MMSE in 9 studies [14,15,18,22,24-28], with CDR in 3 studies [13,16,23], and with both tests for 2 studies [20,29]. Disease severity was not specified in three studies [17,21,23]. Four studies included community dwelling patients $[13,15,17,25]$ and 11 studies included both patients in community and in institution [14,16,18,2024,27-29]. The place of living was not specified in 2 studies $[19,26]$.

Thirteen studies specified the mean age of the sample of patients ranging from 70,5 to 81,8 years [13-20,22,25,26,28,29]. Two studies included patients aged from 50 to over 80 years $[21,24]$.

\section{Perspective of the analysis and costs assessed}

The adopted perspective was the society in 13 studies [13-16,18,20-24,27-29] and respectively the family and the healthcare payer in two studies $[17,19]$. Fourteen studies quantified direct medical and non-medical costs and informal costs $[14,15,17,18,20-29]$. Two studies did not include inpatient costs $[17,25]$. Informal costs were defined as direct non-medical costs in seven studies $[14,15,17,19,22,23,25]$ and as indirect costs in seven studies [18,21,24,26-29]. One study quantified all the costs (i.e. direct, informal and indirect) [13], indirect costs were defined as patient early retirement and informal costs as direct non-medical costs. Danish study quantified only direct medical and non-medical costs [16]. German study quantified only direct medical costs [19].

\section{Estimating resource consumption}

Three studies estimated resource consumption retrospectively $[15,21,29]$. Two of them used bottom-up approach to gather activity data through questionnaires $[15,29]$. The other used a top-down approach, using published national indicators, national surveys and published studies [21]. Eleven studies estimated resource consumption prospectively [13,14,16-18,20,22-24,26,28]. Two studies used mainly the Resource Utilisation in Dementia (RUD) [48] to gather activity data [14,18], completed with report forms, medical records and questionnaires on 560 patients in the Spanish study [14]. Nine studies gathered activity data mainly with questionnaires $[13,16,17,20,22,23,25,26,28]$. In the Danish study, 164 AD couple (i.e. patients/caregivers) was interviewed at home about Activities of Daily Living (ADL), use of health care and community services [16]. Two US studies measured direct costs using caregiver's interviews and Medicare Current Beneficiary Survey (MCBS) [13,23]. 


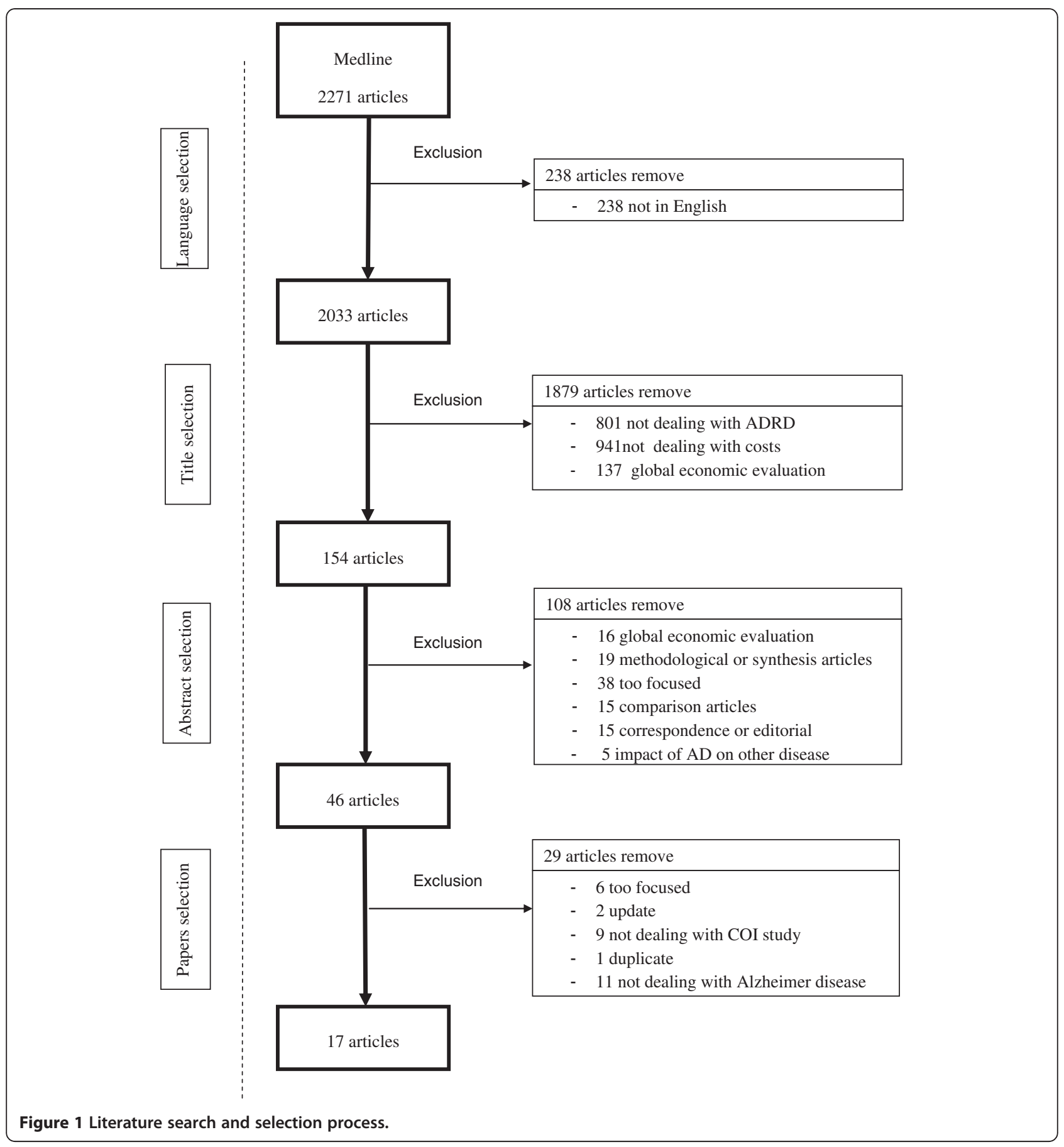

Rice et al. gathered activity data through monthly caregiver's telephone interviews, billing records and with calendar given to caregiver at the baseline visit [23]. Israeli study used a baseline questionnaire to record time spent on caring and use of goods and services, and secondly recorded the same items with 5 monthly telephone interviews [28]. Two studies recorded data via mailed questionnaires filled out by caregivers [13,17]. Turkish study used a questionnaire and daily time sheets for caregiving time
[25]. Wang et al. interviewed 66 AD couples for filling out the resource use's questionnaire [26]. Two studies used decision modelling [19,27] and estimated resources with published sources and national surveys [27] or with data extractions of a German retrospective analysis [19]. One study did not precise the approach used to gather activity data [24]. Eight studies specified the number of caregiver included, several for 4 studies $[13,15,17,22]$ and only one for others $[18,23,25,28]$. Eight 
Table 2 Cost of illness studie's characteristics in Alzheimer disease

\begin{tabular}{|c|c|c|c|c|c|c|c|c|c|c|}
\hline Study & Country & $\begin{array}{c}\text { Type of helthcare system } \\
\text { (insurance) }\end{array}$ & $\begin{array}{c}\text { Year of } \\
\text { valuation }\end{array}$ & Currency & Perspective & $\begin{array}{l}\text { Design of cost } \\
\text { analysis }\end{array}$ & $\begin{array}{l}\text { Sample } \\
\text { size }\end{array}$ & Type of setting & $\begin{array}{l}\text { Follow-up } \\
\text { (months) }\end{array}$ & $\begin{array}{l}\text { Total annual cost per } \\
\text { patient (US\$) }\end{array}$ \\
\hline $\begin{array}{l}\text { Lopez Bastida et al. } \\
\text { [13] }\end{array}$ & Spain & Public social & 2001 & $€$ & Societal & Prosepective & 237 & At home & 12 & 37,881 \\
\hline Coduras et al. [14] & Spain & Public social & 2006 & $€$ & Societal & $\begin{array}{l}\text { Prospective } \\
\text { multicentre }\end{array}$ & 560 & $\begin{array}{l}\text { At home and in } \\
\text { institution }\end{array}$ & 12 & 22,558 \\
\hline Rigaud et al. [15] & France & Public social & 1996 & $€$ & Societal & $\begin{array}{l}\text { Retrospective } \\
\text { single centre }\end{array}$ & 48 & At home & 6 & 31,153 \\
\hline $\begin{array}{l}\text { Kronborg Andersen } \\
\text { et al. [16] }\end{array}$ & Denmark & Public social & 1997 & DKK & Societal & $\begin{array}{l}\text { Prospective single } \\
\text { centre }\end{array}$ & 164 & $\begin{array}{l}\text { At home and in } \\
\text { institution }\end{array}$ & 12 & 17,078 \\
\hline Cavallo et al. [17] & Italy & Public and private & 1995 & $£$ & Family & $\begin{array}{l}\text { Prospective single } \\
\text { centre }\end{array}$ & 423 & At home & NS & 52,954 \\
\hline Mesterton et al. [18] & Sweden & Public social & 2007 & SEK & Societal & $\begin{array}{l}\text { Prospective } \\
\text { multicentre }\end{array}$ & 233 & $\begin{array}{l}\text { At home and in } \\
\text { institution }\end{array}$ & 1 & 46,956 \\
\hline Kiencke et al. [19] & Germany & Public health & 2005 & $€$ & $\begin{array}{l}\text { Healthcare } \\
\text { payer }\end{array}$ & Decision model & 21512 & NS & 60 & 11,786 \\
\hline Leon et al. [20] & USA & Private & 1996 & US\$ & Societal & $\begin{array}{l}\text { Prospective } \\
\text { multicentre }\end{array}$ & 150 & $\begin{array}{l}\text { At home and in } \\
\text { institution }\end{array}$ & 1 & 18,804 \\
\hline Hay et al. [21] & USA & Private & 1983 & US\$ & Societal & Retrospective & NS & $\begin{array}{l}\text { At home and in } \\
\text { institution }\end{array}$ & Lifetime & $18,517^{*}$ \\
\hline Rice et al. [22] & USA & Private & 1990 & US\$ & Societal & $\begin{array}{l}\text { Prospective } \\
\text { multicentre }\end{array}$ & 187 & $\begin{array}{l}\text { At home and in } \\
\text { institution }\end{array}$ & 12 & $51,905^{*}$ \\
\hline Leon et al. [23] & USA & Private & 1996 & US\$ & Societal & $\begin{array}{l}\text { Prospective } \\
\text { multicentre }\end{array}$ & 679 & $\begin{array}{l}\text { At home and in } \\
\text { institution }\end{array}$ & NS & 27,672 \\
\hline Ostbye et al. [24] & Canada & Public social & 1991 & CAN\$ & Societal & Not specify & 10263 & $\begin{array}{l}\text { At home and in } \\
\text { institution }\end{array}$ & NS & $13,900^{*}$ \\
\hline Zencir et al. [25] & Turkey & Public and private & 2003 & TRY & NS & Prosepective & 42 & At home & 3 & 3,492 \\
\hline Wang et al. [26] & China & Public social insurance & 2006 & $\mathrm{RMB}$ & NS & $\begin{array}{l}\text { Prospective single } \\
\text { centre }\end{array}$ & 66 & NS & 12 & $2,935^{*}$ \\
\hline Suh et al. [27] & Korea & Private & 2002 & \# & Societal & Decision model & NS & $\begin{array}{l}\text { At home and in } \\
\text { institution }\end{array}$ & 12 & 11,389 \\
\hline Beeri et al. [28] & Israel & Public social & 1999 & NIS & Societal & $\begin{array}{l}\text { Prospective } \\
\text { multicentre }\end{array}$ & 121 & $\begin{array}{l}\text { At home and in } \\
\text { institution }\end{array}$ & 6 & $19,893^{*}$ \\
\hline Allegri et al. [29] & Argentina & Public and private & 2001 & $\$ A r$ & Societal & Retrospective & 100 & $\begin{array}{l}\text { At home and in } \\
\text { institution }\end{array}$ & 3 & 7,709 \\
\hline
\end{tabular}

NS: not specify; NA: not available, ${ }^{*}$ Net Costs.

All costs are in US\$ $(1 €=1,36491$ US\$, 1 CAN\$ =0,970458 US\$, 1 DKK =0,183360 US\$, 1 RMB =0,156987 US\$; October 11, 2011) SEK, Swedish Crown; RMB, Yuan Renminbi; Israeli Shekel; TRI, Turkish Lira; CAN\$, Canadian Dollar; DKK, Danish Crown; €, Euro). 
Table 3 Total annual costs disaggregation

\begin{tabular}{|c|c|c|c|c|c|c|c|c|c|c|c|c|c|c|}
\hline Study & $\begin{array}{l}\text { Total annual cost } \\
\text { per patient (US\$) }\end{array}$ & $\begin{array}{c}\text { Direct } \\
\text { medical } \\
\text { costs }\end{array}$ & Inpatient & Outpatient & Medication & $\begin{array}{l}\text { Specialized } \\
\text { institution }\end{array}$ & Other & $\begin{array}{l}\text { Direct non } \\
\text { medical costs }\end{array}$ & $\begin{array}{l}\text { Home } \\
\text { help }\end{array}$ & $\begin{array}{l}\text { Nursing } \\
\text { home }\end{array}$ & Transportation & Other & $\begin{array}{l}\text { Informal } \\
\text { costs }\end{array}$ & $\begin{array}{l}\text { Indirect } \\
\text { costs }\end{array}$ \\
\hline $\begin{array}{l}\text { Lopez Bastida } \\
\text { et al. [13] }\end{array}$ & 37,881 & 4,848 & 924 & 844 & 2,468 & 301 & 311 & 2,306 & 2,223 & NA & 83 & NA & 29,884 & 843 \\
\hline $\begin{array}{l}\text { Coduras et al. } \\
\text { [14] }\end{array}$ & 22,558 & 4,744 & 144 & 503 & 2,137 & 1,97 & NA & 5,798 & 4,66 & 1,138 & NA & NA & 12,016 & NA \\
\hline $\begin{array}{l}\text { Rigaud et al. } \\
\text { [15] }\end{array}$ & 31,153 & 6,663 & NS & NS & NS & NS & NA & 5,632 & 5,632 & NS & NS & NA & 18,858 & NA \\
\hline $\begin{array}{l}\text { Kronborg } \\
\text { Andersen et al. } \\
\text { [16] }\end{array}$ & 17,078 & 4,357 & 4,11 & 247 & NA & NA & NA & 12,721 & 12,663 & NA & NA & 58 & NA & NA \\
\hline $\begin{array}{l}\text { Cavallo et al. } \\
\text { [17] }\end{array}$ & 52,954 & 2,722 & NA & NA & NA & 2,722 & NA & 5,496 & 5,496 & NA & NA & NA & 44,736 & NA \\
\hline $\begin{array}{l}\text { Mesterton et al. } \\
\text { [18] }\end{array}$ & 46,956 & 3,155 & 1,067 & 1,118 & 970 & NA & NA & 39,373 & 6,487 & 32,886 & NA & NA & 4,428 & NA \\
\hline $\begin{array}{l}\text { Kiencke et al. } \\
\text { [19] }\end{array}$ & 11,786 & 11,786 & 2,889 & 1,449 & 2,126 & NS & 677 & NA & NA & NA & NA & NA & NA & NA \\
\hline Leon et al. [20] & 18,804 & 7,284 & NS & NS & NS & NA & NA & NA & NA & NA & NA & NA & 11,52 & NA \\
\hline Hay et al. [21] & $18,517^{*}$ & 2,292 & 756 & 1,292 & 244 & NA & NA & 7,285 & 1,774 & 5,326 & 167 & 18 & 9 & NA \\
\hline Rice et al. [22] & $51,905^{*}$ & 22,176 & 1,072 & 545 & 301 & 19,521 & 737 & 9,699 & 9,585 & NA & NA & 114 & 20,03 & NA \\
\hline Leon et al. [23] & 27,672 & 21,924 & NS & NS & NS & NS & NS & NA & NA & NA & NA & NA & 5,748 & NA \\
\hline $\begin{array}{l}\text { Ostbye et al. } \\
{[24]}\end{array}$ & $13,900^{*}$ & NS & NS & NS & NS & NS & NS & NS & NS & NS & NA & NS & NS & NA \\
\hline Zencir et al. [25] & 3,492 & 2,128 & NA & 37 & 2091 & NA & NA & NA & NA & NA & NA & NA & 1,364 & NA \\
\hline Wang et al. [26] & $2,935^{*}$ & 863 & 29 & 32 & 802 & NA & 11 & 431 & 373 & NA & NA & 27 & 1,63 & NA \\
\hline Suh et al. [27] & 11,389 & 4,394 & NS & NS & NS & NA & NA & 445 & 445 & NA & NA & NA & 6,55 & NA \\
\hline Beeri et al. [28] & $19,893^{*}$ & 3,974 & 1,749 & 1,63 & 584 & NA & 11 & 9,326 & 1,822 & 7,504 & NA & NA & 6,593 & NA \\
\hline Allegri et al. [29] & 7,709 & 3,389 & 525 & 280 & 2,389 & NA & 195 & 2,488 & 187 & 2,301 & NA & NA & 1,832 & NA \\
\hline
\end{tabular}

NS: not specify; NA: not available, * Net Costs.

SEK, Swedish Crown; RMB, Yuan Renminbi; Won; \$Ar, Argentine Peso; NIS, New Israeli Shekel; TRI, Turkish Lira; CAN\$, Canadian Dollar; DKK, Danish Crown; $€$, Euro). 
studies recorded AD net costs [15,16,21,22,24,26,28,29] either by subtracting healthy patient costs or by asking AD couple about resource's used exclusively for AD.

The follow-up period was the lifetime in the study which adopted the incidence-based approach [21] and was one year in six studies [13,14,16,22,26,27], but was frequently reduced to six, three or one month $[14,18,20,25,28,29]$. One study used a sixty months follow-up period [19].

\section{Valuation of unit costs}

Direct costs were estimated from published data, national estimates and Medicare-over charges in one American study [21], and from unit costs using the MCBS and national estimates for adult day care in another one [20]. Rice et al. used charges and bills provided by the caregivers [22]. Two Spanish studies used the Spanish database on medical costs (SOIKOS), patient's reports and the Spanish Vademecum to estimate unit costs $[13,14]$. Direct unit costs were based on reimbursement tariffs used by the French social health insurance and on the French Disease related group (DRG) for inpatient care [15]. The Danish study used the reimbursement tariffs of social insurance, hospital accounts, gross wage rates of professionals and amortization procedure to value direct costs [16]. Institutional costs were valued with the average cost per day without food and beverage. Zencir et al. valued unit costs with the average price of public and private physician visits and with the average price per day for medication [25]. In the Chinese study, unit costs were valued with drugs prices, transportation reimbursements and local fees for home help [26]. Tariffs of social health insurance and full drugstore prices were used to unit costs valuation in the Argentinian study [28]. Meserton et al. valued unit costs with ward-specific per diem costs from regional price, the lowest available price for medication and with per visit costs [21]. For residential care, the number of days in institution was multiplied by the corresponding unit costs. Two studies used national estimates to value unit costs [23,27]. No information relating to direct costs valuation was reported in four studies [17-19,24]. Twelve studies used the replacement cost approach to value informal care [13,15,17,20-26,28,29]. Seven studies used national estimates of a close substitute $[17,20-23,25,29]$. Among these, 5 studies used different national wages to value different caregiver's activities [17,20,22,23,28]. Israeli study obtained different hourly wage rates for each activity from the Central Bureau of Statistics [28] and Leon et al. used hourly wage of home health aids to value ADL time and homemaker's hourly wage to value IADL time [23]. Two studies used hospital nurse hourly wage [21,25], another one, local wage rate without specifying the type of professional caregiver [26] and the Canadian study used published data [24]. Three studies did not specify the sources used to value informal care time [13,15,29]. Nevertheless, one study used professional caregiver monthly salary [29], another the cost per hour of a domestic cleaner gross wage [13] and the last one the average between housekeeping and paid assistance wage [15]. One study chose opportunity cost approach to value informal care, using the mean informal caregiver own salary [14]. Both approaches were used in one study [27]. The time spent by working caregivers was valued with national estimates and the time spent by working caregivers was valued with the own caregivers salaries. Opportunity cost and revealed preference approaches were used to value informal costs in one study [18]. Caregiving time was valued either with the HCA (working caregivers) or with a monetary estimate value of one hour of leisure time (not working caregivers). One study valued indirect costs with national estimates on employment and wages [13].

\section{Discounting costs}

One study has discounted costs without specifying the discounting rate [21]. German study performed costs discounting in the sensitivity analysis [19]. All the other studies used a short follow-up period and had no need to discount costs.

\section{Sensitivity analysis}

Only three studies performed a sensitivity analysis $[14,27,29]$. One study analyzed the impact of informal costs variation [14], another one the variation of $\mathrm{AD}$ sufferers' proportion according to the need of full time care level [27], and the last one the discounting of the incurred costs [19].

\section{Presentation of results}

Most studies presented their results clearly. They were mainly well explained and consistently set out in relation to the methods adopted. Five studies did not sufficiently disaggregate costs, so the information strength was reduced (Table 3) $[15,20,23,24,27]$. All studies presented results in terms of cost per patient. Four studies proposed also AD total costs for the country $[13,23,24,27]$. According to the key methodological points, we have drafted a checklist of questions related to the eight items analyzed (Table 1). For 9 studies, the answers of at least seven to eleven questions were "yes" [13,14,16,18,20,21,26,27,29].

\section{Conclusion}

This study reviewed seventeen COI studies on AD with the main goal of analyzing the various methodologies. According to the key methodological points, nine studies scored "yes" on the majority of the questions $[13,14,16$, $18,19,21,26,27,29]$. 
In this review, annual cost per patient varies from $\$ 2,935$ to $\$ 52,954$, confirming the costly character of AD. Nevertheless, commenting on these quantitative results is a problem because different approaches have been adopted. Informal care time varies widely according to the tool used. Validated instruments such as RUD, Caregiver Activity Survey (CAS) or Caregiver Activity Time Survey (CATS) exist to estimate informal care time [48-50]. Most often, time spent in ADL and IADL was used but they measure dependence and not specifically AD caregiving time. Opportunity cost underestimates the time of women, elderly and minority that suffer from discrimination in labour market [51], and does not allow the valuation of different informal caregiving activities. These activities change can be considered with the replacement cost approach. Informal costs vary with the number of caregiver included. Informal costs can be 8 times higher if several caregivers are included rather than just one. AD informal costs have to be rigorously quantified because they represent $36 \%$ to $85 \%$ of total costs [9].

Unlike clinical trial results, it is very difficult to generalize results of economic studies conducted in different countries. Economic results are difficult to compare because of monetary issues (i.e. fluctuating exchange rates, purchasing powers of currencies). According to the World Bank classification [52], 3 studies in this review were conducted in upper middle income economies [25,26,29] and presented a mean annual cost for an $\mathrm{AD}$ patients which is 5 times lower than in studies conducted in high income economies. Purchasing Power Parity (PPP) use could help results comparison because it eliminates price levels differences between countries [53].

Domestic characteristics also affect resource consumption and unit costs, including differences in clinical practice and healthcare system framework. For example, medication costs can vary between studies because of the use of tariffs in solidarity systems which are not comparable to free prices in private systems.

Follow-up periods found in this review were often less than one year, which is a short period to assess chronic disease costs. However, data collection over a long period is difficult so the use of models could compensate this difficulty.

Some limitations are present in this review as only English papers were selected, which restricted our sample. Another limitation is based on the lack of items weighting (Table 1). It is likely that results are more significantly affected by some items than others. Further works must be performed in this area.

Nevertheless, this study built an inventory on the methodology used to analyze AD costs and helped in better understanding the reasons of disparate results between studies.
COI results are the basis for economic evaluations and provide information for models that is a part of any efficiency evaluation [45]. Nevertheless, an insufficient description of methods may lead to misunderstandings. COI studies identified in this review highlight the poor consensus of methodological approaches. Medical journal should encourage researchers to give clear descriptions and discuss limitations, and a further effort should be made to validate methodology. The definition of standards, with a large consensus in the methodology selected to conduct this studies, should be a major concern for the scientific community. A collective awareness about disease burden exists between economists, policies and caregivers that may lead to relevant decision making. COI studies can serve as a basis for projecting disease expenses, and thus allow adapting medical and social disease management in order to control AD costs.

\section{Abbreviations}

AD: Alzheimer disease; ADL: Activity of Daily Living; CAS: Caregiver Activity Survey; CATS: Caregiver Activity Time survey; COI: Cost of illness study; CDR: Clinical Dementia Rate; DSM: Diagnostic and Statistical Manual of Mental Disorders; DRG: Disease Related Group; HCA: Human Capital Approach; IADL: Instrumental Activity of Daily Living; MCBS: Medicare Current Beneficiary Survey; MMSE: Mini Mental State Examination; N: No; NINCDSADRDA: National Institute of Neurological and Communicative Disorders and Stroke and the Alzheimer's Disease and Related Disorders Association; NA: Not Applicable; NS: Not Specified; NM: Not Measured; MNS: Measured but Not Specified; P: Partially; PPP: Purchasing Power Parity; RUD: Resource Utilization in Dementia; Y: Yes.

\section{Competing interests}

The authors declare that they have no competing interests.

\section{Authors' contributions}

NC supervised the project and its implementation, conducted the literature review, drafted the article and approved his final version. LM designed the study and helped supervise the project and its implementation, conducted the literature review, drafted the article and approved his final version. HD and TR helped to implement the project, conducted the literature review, reviewed the article and approved final version.VG and LF helped conduct the literature review, reviewed the article and approved his final version. SG, $\mathrm{SA}, \mathrm{ML}, \mathrm{AG}$ and $\mathrm{BV}$ helped the interpretation of data, reviewed the article and approved his final version. All authors read and approved the final manuscript.

\section{Financial support}

This study was supported by a grant from the French Ministry of Health (PHRCN 2008, 0811101 ).

\section{Acknowledgements}

We gratefully acknowledge B. Giachetto for assistance.

\section{Author details}

'Department of Medical Information, University Hospital of Toulouse, Toulouse F-31059, France. '2UMR 1027, INSERM, Toulouse F-31059, France. ${ }^{3}$ UMR 1027, University of Toulouse III, Toulouse F-31059, France. ${ }^{4}$ Universty of Paris Descartes, Paris 75016, France. ${ }^{5}$ Department of geriatric medicine, University hospital of Toulouse, Toulouse F-31073, France. ${ }^{6}$ Department of Epidemiology and Public Health, University Hospital of Toulouse, Toulouse F-31059, France. ${ }^{7}$ EDISS, University of Lyon I, Villeurbanne F-69100, France.

Received: 5 June 2012 Accepted: 27 August 2012

Published: 11 September 2012 


\section{References}

1. Byford S, Torgerson DJ, Raftery J: Cost of illness studies. BMJ 2000, 320:1335.

2. Koopmanschap MA: Cost of illness studies: Useful for health policy? PharmacoEconomics 1998, 14(2):143-148.

3. Hogdson TA: Annual costs of illness versus Lifetime costs of illness and implications of structural change. Drug Inf J 1988, 22:323-341.

4. Alzheimer's Association Reports: 2011 Alzheimer's disease facts and figures. WV Med J 2011, 107(3):82-83.

5. Wimo A, Prince M: World Alzheimer Report 2011, The global Economic Impact of Dementia. Alzheimer Disease Int 2010, 1-52.

6. O'Brien BJ, Goeree R, Hux M, Iskedjian M, Blackhouse G, Gagnon M, Gauthier S: Economic evaluation of donepezil for the treatment of Alzheimer's disease in Canada. Journal Am Gerriatr soc 1999, 47(5):570-578.

7. Hill JW, Futterman R, Mastey V, Fillit $\mathrm{H}$ : The effect of donepezil therapy on health costs in a Medicare managed plan. Manag Care Interface 2002, 15(3):63-70.

8. Jönsson L, Wimo A: The cost of dementia in Europe: a review of the evidence, and methodological considerations. PharmacoEconomics 2009, 27(5):391-403

9. Mauskopf J, Mucha L: A review of the methods used to estimate the cost of Alzheimer's disease in the United States. Am J Alzheimers Dis Other Demen 2011, 26(4):298-309.

10. McDaid D: Estimating the costs of informal care for people with Alzheimer's disease: methodological and practical challenges. Int J Geriatr Psychiatry 2001, 16(4):400-405.

11. Drummond MF: Methods for the economic evaluation of health care programmes. 3rd edition. Oxford: Oxford University Press; 2005.

12. Molinier L, Bauvin E, Combescure C, Castelli C, Rebillard X, Soulié M, Daurès JP, Grosclaude P: Methodological considerations in cost of prostate cancer studies: a systematic review. Value Health 2008, 11(5):878-885.

13. Lopez-Bastida J, Serrano-Aguilar P, Perestelo-Perez L, Oliva-Moreno J: Socialeconomic costs and quality of life of Alzheimer disease in the Canary Islands, Spain. Neurology 2006, 26;67(12):2186-2191.

14. Coduras A, Rabasa I, Frank A, Bermejo-Pareja F, López-Pousa S, López-Arrieta JM, Del Llano J, León T, Rejas J: Prospective one-year cost-of-illness study in a cohort of patients with dementia of Alzheimer's disease type in Spain: the ECO study. J Alzheimers Dis 2010, 19(2):601-615.

15. Rigaud AS, Fagnani F, Bayle C, Latour F, Traykov L, Forette F: Patients with Alzheimer's disease living at home in France: costs and consequences of the disease. J Geriatr Psychiatry Neuro 2003, 16(3):140-145.

16. Kronborg Andersen C, Søgaard J, Hansen E, Kragh-Sørensen A, Hastrup L, Andersen J, Andersen K, Lolk A, Nielsen H, Kragh-Sørensen P: The cost of dementia in Denmark: the Odense Study. Dement Geriatr Cogn Disord 1999, 10(4):295-304

17. Cavallo MC, Fattore G: The economic and social burden of Alzheimer disease on families in the Lombardy region of Italy. Alzheimer Dis Assoc Disord 1997, 11(4):184-190.

18. Mesterton J, Wimo A, By A, Langworth S, Winblad B, Jönsson L: Cross sectional observational study on the societal costs of Alzheimer's disease. Curr Alzheimer Res 2010, 7(4):358-367.

19. Kiencke P, Dietmar D, Grimm C, Rychlik R: Direct costs of Alzheimer disease in Germany. Eur J Health Econ 2011, 12:533-539.

20. Leon J, Neumann PJ: The cost of Alzheimer's disease in managed care: a cross-sectional study. Am J Manag Care 1999, 5(7):867-877.

21. Hay JW, Ernst RL: The economic costs of Alzheimer's disease. Am J Public Health 1987, 77(9):1169-1175.

22. Rice DP, Fox PJ, Max W, Webber PA, Lindeman DA, Hauck WW, Segura E: The economic burden of Alzheimer's disease care. Health Aff 1993, 12(2):164-176.

23. Leon J, Cheng CK, Neumann PJ: Alzheimer's disease care: costs and potential savings. Health Aff 1998, 17(6):206-216.

24. Ostbye T, Crosse E: Net economic costs of dementia in Canada. CMAJ 1994, 15;151(10):1457-1464.

25. Zencir M, Kuzu N, Beşer NG, Ergin A, Catak B, Sahiner T: Cost of Alzheimer's disease in a developing country setting. Int J Geriatr Psychiatry 2005, 20 (7):616-622

26. Wang G, Cheng Q, Zhang S, Bai L, Zeng J, Cui PJ, Zhang T, Sun ZK, Ren RJ, Deng YL, Xu W, Wang Y, Chen SD: Economic impact of dementia in developing countries: an evaluation of Alzheimer-type dementia in Shanghai, China. J Alzheimers Dis 2008, 15(1):109-115.
27. Suh GH, Knapp M, Kang CJ: The economic costs of dementia in Korea, 2002. Int J Geriatr Psychiatry 2006, 21(8):722-728.

28. Beeri MS, Werner P, Adar Z, Davidson M, Noy S: Economic cost of Alzheimer disease in Israel. Alzheimer Dis Assoc Disord 2002, 16(2):73-80.

29. Allegri RF, Butman J, Arizaga RL, Machnicki G, Serrano C, Taragano FE, Sarasola D, Lon L: Economic impact of dementia in developing countries: an evaluation of costs of Alzheimer-type dementia in Argentina. Int Psychogeriatr 2007, 19(4):705-718.

30. McKhann G, Drachman D, Folstein M, Katzman R, Price D, Stadlan EM: Clinical diagnosis of Alzheimer's disease: report of the NINCDS-ADRDA Work Group under the auspices of Department of Health and Human Services Task Force on Alzheimer's Disease. Neurology 1984 34(7):939-944.

31. American Psychiatric Association: Diagnostic and Statistical Manual of Mental disorders. 4th editionWashington DC: American Psychiatric Association; 2000.

32. Quentin W, Riedel-Heller S, Luppa M, Rudolph A, König HH: Cost of illness studies of dementia: a systematic review focusing on stage dependency of costs. Acta Psyciatra Scandinavia 2010, 121:243-259.

33. Small GW, McDonnell DD, Brooks RL, Papadopoulos G: The impact of symptom severity on the cost of Alzheimer disease. Journal American Geriatric society 2002, 50(2):321-327

34. Mauskopf J, Racketa J, Sherrill E: Alzheimer's disease: the strength of association of costs with different measures of disease severity. J Nutr Health Aging 2010, 14(8):655-663.

35. Herman N, Tam DY, Balshaw R, Sambrook R, Lesnikova N, Lanctôt KL: Canadian Outcomes Study in Dementia [COSID] Investigators, The relation between disease severity and cost of caring for patients with Alzheimer disease in Canada. Can J Psychiatry 2010, 55(12):768-775.

36. Morris JC: The Clinical Dementia Rating [CDR]: current version and scoring rules. Neurology 1983, 43:2412-2414.

37. Crum RM, Anthony JC, Bassett SS, Folstein MF: Population-based norms for the mini-mental state examination by age and educational level. JAMA 1993, 269:2386-2389.

38. Zhu CW, Scarmeas N, Torgan R, Albert M, Brandt J, Blacker D, Sano M, Stern Y Longitudinal study of effects on patient characteristics on direct costs in Alzheimer disease. Neurology 2006, 67(6):998-1005.

39. Tarricone R: Cost of illness analysis. What room in health economics. Health Policy 2006, 77:51-63.

40. Koopmanschap MA, Rutten FF: Indirect costs in economic studies: confronting the confusion. PharmacoEconomics 1993, 4:446-454.

41. Koopmanschap MA, van Ineveld BM: Towards a new approach for estimating costs of disease. Soc Sci Med 1992, 34(9):1005-1010.

42. Hogdson TA, Meiners MR: Cost of illness methodology a guide to current practices and procedures. Milbank Mem Fund Q Health Soc 1982, 60(3):429-462

43. Van der Berg B, Brouwer W, Van Exel J, Koopmanschap M, Van den Bos GAM, Rutten F: Economic valuation of informal care: lessons from the application of the opportunity costs and proxy goods methods. Soc Sci Med 2006, 62:835-845.

44. Koopmanschap MA, Van Exel JN, Van den Berg B, Brouwer WB: An overwiew of methods and application to value informal care in economic evaluation of healthcare. PharmacoEconomics 2008, 26(4):269-280

45. Gold MR, Russel LB, Siegel JE, Daniels N, Weinstein MC: Cost effectiveness in Health and Medicine. JAMA 1996, 276(14):1172-1177.

46. Agro KE, Bradley CA, Mittmann N, et al: Sensitivity analysis in health economic and pharmacoeconomic studies. An appraisal of the literature. Pharmacoeconomics 1997, 11:75-88

47. Wiseman $\mathrm{V}$, Mooney $\mathrm{G}$ : Burden of illness estimates for priority setting: a debate revisited. Health Policy 1998, 43:243-251.

48. Wimo A, Nordberg G, Jansson W, Grafström M: Assessment of informal services to demented people with the RUD instrument. Int J Geriatr Psychiatry 2000, 15(10):969-971

49. Davis KL, Marin DB, Kane R, Patrick D, Peskind ER, Raskind MA, Puder KL: The Caregiver Activity Survey [CAS]: development and validation of a new measure for caregivers of persons with Alzheimer's disease. Int I Geriatr Psychiatry 1997, 12(10):978-988.

50. Clipp EC, Moore MJ: Caregiver time use: an outcome measure in clinical trial research on Alzheimer's disease. Clin Pharmacol Ther 1995, 58(2):228-236 
51. Segel JE: Cost-of-Illness studies-A primer, RTI -UNC Center of Excellence in Health Promotion Economics. RTI international. 2006:1-39. http://www.rti. org/pubs/coi_primer.pdf

52. World Bank: World Bank -list economies.Country and lending groups. 2011. http://data.worldbank.org/about/country-classifications/country-andlendinggroups\#Upper_middle_income 1. (Accessed October 26, 2011).

53. Schreyer P, Koechlin F: Purchasing power parities: measurement and uses. Statistics breaf. OECD Statistics brief 2002, 3:1-8.

doi:10.1186/2191-1991-2-18

Cite this article as: Costa et al:: Methodological considerations in cost of illness studies on Alzheimer disease. Health Economics Review 2012 2:18.

Submit your manuscript to a SpringerOpen ${ }^{\circ}$ journal and benefit from:

- Convenient online submission

- Rigorous peer review

- Immediate publication on acceptance

- Open access: articles freely available online

- High visibility within the field

- Retaining the copyright to your article

Submit your next manuscript at $\gg$ springeropen.com 